\title{
PHYTOTOXICITY OF OIL SHALE SEMI-COKE AND ITS AQUEOUS EXTRACTS: A STUDY BY SEED GERMINATION BIOASSAY
}

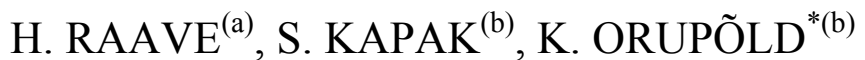 \\ (a) Institute of Agricultural and Environmental Sciences, Estonian University of \\ Life Science, Kreutzwaldi 56, 51014, Tartu, Estonia \\ (b) Institute of Physical Chemistry, University of Tartu, Jakobi 2, 51014 Tartu, \\ Estonia
}

\begin{abstract}
Phytotoxicity of oil shale semi-coke has been studied by germination bioassay. Timothy (Phleum pratense) seeds were germinated on solid semicoke and in its water extracts. Fresh semi-coke completely blocked seed germination but weathering significantly decreased its inhibition effect. The inhibitory effect of aqueous extracts was less than that of solid semi-coke, and it decreased as the liquid-to-solid ratio used for preparing the extracts increased. The inhibition of seed germination was mainly caused by high content of soluble salts in semi-coke. Good correlations were found between seed germination and electrical conductivity, and $\mathrm{Ca}^{2+}$ content of water extracts.
\end{abstract}

\section{Introduction}

Up to the present, suitability of oil shale semi-coke for seed germination has been studied only rarely. However, taking into account the need to cover semi-coke dumping sites and the fact that covering semi-coke heaps by plants enhances bioremediation of semi-coke to a great extent [1], the question is currently of high interest. The few experiments carried out for growing grasses on semi-coke show that fresh semi-coke inhibits seed germination, i.e. the seeds sown on the fresh semi-coke do not germinate [2]. However, it has been also shown that the mixing of semi-coke with acidic sphagnum peat and weathering decrease the inhibition effect of semi-coke [2]. Trials on semi-coke heaps have revealed that seeds can easily germinate and grasses grow on semi-coke of several years of age, as well as its weathered mixture with peat. The limiting factors for plant growth on weathered semi-coke are water content and availability of nutrients [3].

\footnotetext{
*Corresponding author: e-mail kajao@chem.ut.ee,kajao@physic.ut.ee
} 
It is not clear what exactly causes phytotoxicity of oil shale semi-coke towards seeds. Oil shale semi-coke is of a most variable composition because of differences in the raw material and the technological processes involved in oil production. Thus, it contains inorganic and organic compounds in varying amounts. Of the organic compounds found in semicoke, phenols and polycyclic aromatic hydrocarbons (PAHs) have inhibited seed germination in different studies [4-8]. It is also known that phenolic compounds are the main components of natural growth regulators [9-10]. However, it is doubtful that these compounds cause the inhibition of seed germination. Phenolic compounds are more biodegradable than the other organic compounds found in semi-coke [11-12], and therefore their influence on seed germination should be shorter than the 6-7 months found in the former studies [2]. The content of PAHs in the semi-coke is rather small, up to $13 \mathrm{mg} / \mathrm{kg}[13,14]$.

Germination of the seeds can be influenced by high $\mathrm{pH}$ of semi-coke, which is higher than 12 in the case of fresh semi-coke and about 10 in the case of semi-coke weathered for several years in heaps [13]. As seeds should germinate better at neutral $\mathrm{pH}$ there is reason to believe that the inhibiting effect of semi-coke on seed germination is at least to some extent caused by its high $\mathrm{pH}$. However, this alone cannot be the sole reason, since the inhibiting effect did not decrease appreciably when $\mathrm{pH}$ of semi-coke decreased after mixing with acidic peat [2].

The investigations published so far have paid no attention to the very high content of soluble inorganic compounds in oil shale semi-coke. It is known that semi-coke contains a high amount of sulphur (1.7-2.1\%) in different forms and calcium oxide (8-14\%) [13]. Ecotoxicological tests on the leachate from semi-coke heaps carried out by A. Kahru et al. [15] have revealed that the ecological risk is up to $25 \%$ caused by sulphur-containing compounds, mostly by sulphides.

It is also evident that high salinity of growth medium can inhibit germination [16-18], mainly by diminishing the water potential of the growth media which in turn hinders water entering into seeds [17, 19]. High concentration of calcium ions can raise osmotic pressure to a level toxic to seeds and plants [20]. Beside the influence on the water potential of the growth medium, a high concentration of ions may also be toxic to the seeds. For instance, it has been shown that the influence of high concentrations of sulphate ions during germination can kill seeds [21].

The aim of the current work was to study oil shale semi-coke by germination bioassay using timothy (Phleum pratense) seeds. Timothy seeds were chosen because timothy is widely spread in Estonia on natural as well as on cultivated grasslands and therefore may be of importance also for recultivating semi-coke heaps. The results of germination tests were compared with the results of chemical analysis in order to test for a correlation between the main chemical properties and phytotoxicological effect of semi-coke. Additionally, attention was paid to the determination of phytotoxicity of 
aqueous extracts of semi-coke and its applicability for phytotoxicity assessment.

\section{Materials and methods}

The samples $(13-14 \mathrm{~kg})$ used in the experiments were taken from the semicoke waste heap owned by Kiviõli Keemiatööstus Ltd. (Estonia). They were collected immediately after disposal.

\section{Preparation of semi-coke water extracts}

For the experiments aqueous extracts of semi-coke of different liquid-tosolid ratios $(\mathrm{L} / \mathrm{S}=0.3 / 1-10 / 1)$ were prepared. The extracts were prepared basically as described in the European standard EN 12457-4:2002. Semicoke was mixed with a certain amount of water and shaken continuously at room temperature in the dark. After $24 \mathrm{~h}$ the suspended solids were allowed to settle, and the eluate was filtered for the following analysis. Analysis of the aqueous extracts for $\mathrm{pH}$, electrical conductivity (EC), sulphides, sulphates, total hardness, calcium ions and chemical oxygen demand (COD) were carried out using standard methods approved for water analysis [22].

\section{Seed germination}

The germination tests were carried out with timothy Phleum pratense c 'Tika' seeds purchased from Jõgeva Plant Breeding Institute, Estonia. To determine the germination in water extracts of semi-coke, 100 seeds in 4 or 5 replicates of each experiment were placed on Petri dishes (diameter $9 \mathrm{~cm}$ ) and located in a growth chamber Termaks with controlled temperature and lighting. Extract $(4 \mathrm{ml})$ was added to each dish; control dishes used only distilled water. The dishes were covered with lids. The conditions for seed germination in the growth chamber were: 3 days at thermoperiod $7{ }^{\circ} \mathrm{C}$ without photoperiod and 10 days at a thermoperiod of $30^{\circ} \mathrm{C}$ ( 8 hours) and $20^{\circ} \mathrm{C}$ (16 hours) and a photoperiod 16 hours and 5 hours in the dark [23]. Some experiments were also carried out with solid semi-coke. In these experiments the bottoms of the Petri dishes were covered with moistened semi-coke (particle size $<4 \mathrm{~mm}$ ), and 100 seeds were pressed gently into the sample surface. All experiments were continued for 13 days.

The numbers of germinated seeds $\left(\mathrm{G}\right.$ and $\mathrm{G}_{0}$ for test solution and control, respectively) were counted, and the lengths of the radicles ( $\mathrm{L}$ and $\mathrm{L}_{0}$, respectively for test and control) were determined. The results were quantified as germination rate $\left(\mathrm{G} \%=\mathrm{G} / \mathrm{G}_{0} \times 100\right)$ and germination index $\left(\mathrm{GI}=\mathrm{G} / \mathrm{G}_{0} \times \mathrm{L} / \mathrm{L}_{0} \times 100\right)$. For the statistical analysis of the experimental data the $t$-test (independent variables) and Multiple regression function of the Statistica 7 program (StatSoft, Inc.) were used. 
Some experiments with semi-coke were performed as pot experiments under lab conditions. For this purpose the pots were filled with fresh semicoke. Seeds (100) were sown and after two weeks the emerged plants were assayed. Plant growth data were compared with the results of chemical analysis in order to study the relationship between chemical and phytotoxicological properties of semi-coke. The content of organic compounds in semi-coke was analysed in the Estonian Environmental Research Centre using internationally accredited methods.

\section{Results and discussion}

\section{Seed germination on oil shale semi-coke}

Experiments revealed that fresh semi-coke is toxic to seeds, thus confirming the results of earlier studies [2]. The seeds did not germinate on fresh semicoke nor were they able to germinate even in pure water after previous contact with it. At the same time, the results of the study indicated that the toxic properties of semi-coke decrease over time. The long-term experiments in pots showed clearly that the germination of seeds was feasible after eight months of aging of semi-coke under laboratory conditions. However, the germination of seeds was achieved only on the top layer of semi-coke. Even after nine months the seeds were not able to germinate on the material taken from the deeper layers of semi-coke (Table 1). A more thorough study of the top layer showed that already the layer down to $10 \mathrm{~cm}$ had different properties. The results in Table 1, indicating that germination in the top 10$\mathrm{cm}$ layer was lower after nine months compared to that after eight months, can be explained by the considerable reduction in phytotoxicity of semi-coke in the thinner layer. The results presented in Table 2 also confirm that remediation takes place probably only in the uppermost five-cm layer.

\section{Table 1. Germination of timothy seeds in semi-coke (sample 1) in pot experiments}

\begin{tabular}{|c|c|c|}
\hline $\begin{array}{c}\text { Time of semi-coke } \\
\text { weathering, months }\end{array}$ & $\begin{array}{c}\text { Germination rate, } \\
\%\end{array}$ & Semi-coke $\mathrm{pH}$ \\
\hline 0 & $0^{\mathrm{a}}$ & 12.66 \\
2 & $0^{\mathrm{a}}$ & 12.63 \\
3 & $0^{\mathrm{a}}$ & nd \\
4 & $0^{\mathrm{a}}$ & nd \\
5 & $0^{\mathrm{a}}$ & nd \\
7 & $34^{\mathrm{a}}$ & nd \\
8 & $56^{\mathrm{a}}$ & $8.62^{\mathrm{a}}$ \\
9 & $31^{\mathrm{b}}$ & $8.62^{\mathrm{b}}$ \\
& $0^{\mathrm{c}}$ & $11.10^{\mathrm{c}}$ \\
& $0^{\mathrm{d}}$ & $11.77^{\mathrm{d}}$ \\
\hline
\end{tabular}

${ }^{\mathrm{a}}$ - top layer, ${ }^{\mathrm{b}}$ - layer 0-10 cm; ${ }^{\mathrm{c}}$ - layer $10-20 \mathrm{~cm},{ }^{\mathrm{d}}$ - layer $20-30 \mathrm{~cm}$, nd - not determined 
Table 2. Timothy seed germination on semi-coke samples having undergone different treatments

\begin{tabular}{|c|c|c|c|c|}
\hline $\begin{array}{l}\text { Semi- } \\
\text { coke } \\
\text { sample }\end{array}$ & $\mathrm{pH}$ & $\begin{array}{l}\text { Germinatio } \\
\text { n rate }, \%\end{array}$ & $\begin{array}{c}\text { Germinatio } \\
\mathrm{n} \text { index } \\
\% \\
\%\end{array}$ & Notes \\
\hline $\begin{array}{l}6 \\
6 \\
6 \\
5 \\
4 \\
6 \\
6 \\
6 \\
6 \\
6\end{array}$ & $\begin{array}{r}12.73 \\
12.71 \\
12.61 \\
10.45 \\
8.30 \\
12.60 \\
11.84 \\
\text { nd } \\
\text { nd } \\
11.86 \\
\\
12.10 \\
12.66 \\
12.65\end{array}$ & $\begin{aligned} 0 \\
0 \\
0 \\
52 \pm 4 \\
30 \pm 19 \\
18.5 \pm 6.5 \\
61.5 \pm 3.5 \\
51 \pm 7 \\
75 \pm 1 \\
65.5 \pm 10.0 \\
2 \pm 1 \\
1.5 \pm 0.9 \\
0\end{aligned}$ & $\begin{array}{c}0 \\
0 \\
0 \\
10 \pm 1 \\
6 \pm 6 \\
0 \\
19 \pm 0.1 \\
3 \pm 0.3 \\
26 \pm 1 \\
27 \pm 5 \\
0 \\
0 \\
0\end{array}$ & $\begin{array}{l}\text { fresh } \\
\text { rinsed, } \mathrm{L} / \mathrm{S}=1 \mathrm{1} / \mathrm{kg} \\
\text { rinsed, } \mathrm{L} / \mathrm{S}=21 / \mathrm{kg} \\
\text { rinsed, } \mathrm{L} / \mathrm{S}=10 \mathrm{l} / \mathrm{kg} \\
\text { aged } 6 \mathrm{months} \text { in lab under wet conditions } \\
\text { rinsed, } \mathrm{L} / \mathrm{S}=301 / \mathrm{kg} \\
\text { rinsed, } \mathrm{L} / \mathrm{S}=601 / \mathrm{kg} \\
\text { rinsed, } \mathrm{L} / \mathrm{S}=30 \mathrm{l} / \mathrm{kg} \text {, dried in lab for } 1 \text { week } \\
\text { rinsed, } \mathrm{L} / \mathrm{S}=60 \mathrm{l} / \mathrm{kg} \text {, dried in lab for } 1 \text { week } \\
\text { weathering in lysimeter } 6.5 \text { months, } \\
\text { top layer }(0-5 \mathrm{~cm}) \\
\text { weathering in lysimeter } 6.5 \text { months, } \\
\text { layer } 5-10 \mathrm{~cm} \\
\text { weathering in lysimeter } 6.5 \text { months, } \\
\text { layer } 10-15 \mathrm{~cm} \\
\text { weathering in lysimeter } 6.5 \text { months, } \\
\text { layer } 15-20 \mathrm{~cm}\end{array}$ \\
\hline
\end{tabular}

nd - not determined; ${ }^{*}$ - data are the means of four replications \pm standard deviation

Compared to laboratory conditions, remediation of semi-coke in natural conditions was faster, and germination of seeds was possible there even after only four months of weathering.

It was observed that $\mathrm{pH}$ of semi-coke decreases with time. Under laboratory conditions $\mathrm{pH}$ in the top layer of semi-coke, where the germination of seeds was achieved, decreased after eight months from 12.66 to 8.62. The latter can be considered suitable for plant growth. The $\mathrm{pH}$ of semi-coke in deeper layers was significantly higher than optimal for the seeds or plants. The reduction in phytotoxicity of semi-coke in the top layer can be explained by the decrease in $\mathrm{pH}$ due to the contact with atmospheric $\mathrm{CO}_{2}$. However, the results obtained so far indicate that the high $\mathrm{pH}$ is not the main reason for the inhibition of seed germination. The results show that one of the reasons for the reduction in phytotoxicity is leaching of toxic compounds with water. Comparison of the results in Table 2 reveals that rinsing semi-coke with water improves the germination of seeds more than $\mathrm{pH}$ decrease alone. The seeds can germinate on solid semi-coke after treatment with water (Table 2). The results show considerable reduction in the inhibiting effect of semi-coke rinsed with water under laboratory conditions, or left outside and rinsed with natural rain water.

Besides $\mathrm{pH}$, changes in the content of organic compounds were investigated and their relationship to seed germination studied. The results showed that the phenol content in semi-coke had changed, but there was no decrease 
in oil products or in the content of polar organic compounds (Table 3). The content of organic compounds in different layers did not differ significantly (Table 3) and therefore they cannot be responsible for the inhibition of seed germination to any significant extent. This is also confirmed by the results of experiments with pure substances, which showed that concentrations toxic to seeds are much higher than those found in the semi-coke samples [24].

Table 3. Organic compounds in semi-coke (sample 1)

\begin{tabular}{|l|c|c|c|c|c|}
\hline \multirow{2}{*}{ Compound } & \multicolumn{5}{|c|}{ Content, $\mathrm{mg} / \mathrm{kg}$} \\
\cline { 2 - 6 } & $\begin{array}{c}\text { Fresh } \\
\text { semi-coke }\end{array}$ & $\begin{array}{c}\text { 1 month old } \\
\text { semi-coke }\end{array}$ & \multicolumn{2}{|c|}{9 months old semi-coke } \\
\cline { 4 - 6 } & & & $0-10 \mathrm{~cm}$ & $10-20 \mathrm{~cm}$ & $20-30 \mathrm{~cm}$ \\
\hline Resorcinol & 6.22 & 4.46 & 1.3 & $<0.5$ & $<0.5$ \\
5-methylresorcinol & $<0.5$ & $<0.5$ & $<0.5$ & $<0.5$ & $<0.5$ \\
2,5-dimethylresorcinol & 1.58 & 3.15 & $<0.5$ & $<0.5$ & 0.96 \\
Phenol & 26.7 & 29.5 & 1.97 & 1.28 & 2.35 \\
p-, m- cresol & 12.2 & 12.5 & 1.65 & 1.06 & 2.70 \\
o-cresol & 1.26 & 1.25 & 0.23 & $<0.1$ & 0.31 \\
2,3-dimethylphenol & 1.56 & 1.99 & 0.23 & $<0.1$ & 0.16 \\
2,6-dimethylphenol & 3.30 & 3.43 & $<0.1$ & $<0.1$ & 0.27 \\
3,4-dimethylphenol & 1.85 & 2.4 & $<0.1$ & $<0.1$ & $<0.1$ \\
3,5-dimethylphenol & 3.04 & 1.49 & 0.2 & $<0.1$ & $<0.1$ \\
Oil products & 465 & 333 & 533 & 254 & 395 \\
Polar hydrocarbons & 4058 & 6410 & 5900 & 5110 & 5900 \\
\hline
\end{tabular}

\section{Investigation of water extracts of semi-coke by seed germination bioassay}

Table 4 presents the results of the trials with extracts of semi-coke obtained from different samples by using the most often applied liquid-solid (L/S) ratio $(10 \mathrm{l} / \mathrm{kg})$ in waste characterization. It can be seen that the seed germination rates in semi-coke water extracts $(\mathrm{L} / \mathrm{S}=10)$ were between 72 and $97 \%$ compared to germination in water. More than the germination rate, the radicle length was influenced by water extracts of semi-coke. The developing radicles were much shorter and more branched than those growing in control experiments in water where the average radicle length was $28 \pm 7 \mathrm{~mm}$. The great variation in radicle length also caused considerable variation in germination indexes as can be seen in Table 4 . The chemical parameters in Table 4 show that samples of semi-coke differ quite considerably, although it was not possible to find any significant correlation between chemical parameters and the results of germination studies.

The effects of the semi-coke water extracts obtained by applying different $\mathrm{L} / \mathrm{S}$ ratios in preparing them are given in Table 5 . The germination rate and radicle length depended strongly on the utilized L/S ratio in preparing the extracts (Fig. 1). The germination rate in water extracts of semi-coke 
differed significantly $(p<0.001)$ from that in water in the case of $L / S \leq 2$. More than germination, the $\mathrm{L} / \mathrm{S}$ ratio influenced radicle length. If compared with water, the radicle lengths were shorter in all water extracts studied. Decreasing the L/S ratio $(<1.8)$ used to prepare the extracts from semi-coke increased the negative effect on the seeds, and an inhibition rate similar to that with solid semi-coke samples was obtained. Radicles on the emerged seeds in water extracts were not observed at $\mathrm{L} / \mathrm{S}$ ratios $<1.8$.

Table 4. Influence of semi-coke water extracts $(\mathbf{L} / \mathbf{S}=\mathbf{1 0} \mathbf{~} / \mathbf{k g})$ on germination of timothy seeds

\begin{tabular}{|c|c|c|c|c|c|c|c|c|c|}
\hline $\begin{array}{c}\text { Semi- } \\
\text { coke } \\
\text { sample }\end{array}$ & $\begin{array}{c}\text { Germi- } \\
\text { nation } \\
\text { rate }^{*}, \%\end{array}$ & $\begin{array}{c}\text { Radicle } \\
\text { length }{ }^{*}, \mathrm{~mm}\end{array}$ & $\begin{array}{c}\text { Germi- } \\
\text { nation } \\
\text { index, } \%\end{array}$ & $\mathrm{pH}$ & $\begin{array}{c}\mathrm{EC}, \\
\mathrm{mS} / \mathrm{cm}\end{array}$ & $\begin{array}{c}\mathrm{COD}, \\
\mathrm{mg} / 1\end{array}$ & $\begin{array}{c}\mathrm{Ca}^{2+}, \\
\mathrm{mg} / 1\end{array}$ & $\begin{array}{c}\mathrm{S}^{2-}, \\
\mathrm{mg} / 1\end{array}$ & $\begin{array}{c}\mathrm{SO}_{4}{ }^{2-}, \\
\mathrm{mg} / 1\end{array}$ \\
\hline 2 & $86 \pm 8$ & $7.2 \pm 1.9$ & 50 & 12.81 & nd & 680 & $\mathrm{nd}$ & 309 & nd \\
6 & $82 \pm 7$ & $10.4 \pm 1.7$ & 38 & 13.03 & 7.56 & 396 & 1235 & 102 & 804 \\
6 & $98 \pm 6$ & $16.3 \pm 1.3$ & 50 & 12.89 & 8.31 & 330 & 1034 & 344 & 156 \\
7 & $83 \pm 6$ & $6.8 \pm 0.4$ & 16 & 12.71 & 8.44 & 767 & 1262 & 202 & 250 \\
8 & $72 \pm 6$ & $6.4 \pm 1.2$ & 13 & 12.80 & 7.99 & 584 & 1467 & 152 & 742 \\
9 & $85.5 \pm 7$ & $10.2 \pm 2.5$ & 24 & 12.72 & 7.21 & 549 & 1235 & 128 & 367 \\
10 & $81.5 \pm 12$ & $6.1 \pm 2.5$ & 13 & 12.50 & 6.25 & 1154 & 1158 & 249 & 304 \\
13 & $97 \pm 11$ & $25.9 \pm 0.6$ & 71 & 12.60 & 6.92 & 780 & 1010 & 140 & 100 \\
\hline
\end{tabular}

nd - not determined , ${ }^{*}$ - data are the means of four replications \pm standard deviation

Table 5. Influence of semi-coke (sample 6) water extracts on timothy seeds

\begin{tabular}{|c|c|c|c|c|c|c|c|c|c|}
\hline $\begin{array}{c}\mathrm{L} / \mathrm{S}, \\
1 / \mathrm{kg}\end{array}$ & $\begin{array}{c}\text { Germina- } \\
\text { tion rate*, } \%\end{array}$ & $\begin{array}{c}\text { Radicle } \\
\text { length } \\
\mathrm{mm}\end{array}$ & $\begin{array}{c}\text { Germina } \\
\text { tion index, } \\
\%\end{array}$ & $\mathrm{pH}$ & $\begin{array}{c}\mathrm{EC}, \\
\mathrm{mS} / \mathrm{cm}\end{array}$ & $\begin{array}{c}\mathrm{COD}, \\
\mathrm{mg} / 1\end{array}$ & $\begin{array}{l}\mathrm{Ca}^{2+}, \\
\mathrm{mg} / \mathrm{l}\end{array}$ & $\begin{array}{c}\mathrm{S}^{2-}, \\
\mathrm{mg} / \mathrm{l}\end{array}$ & $\begin{array}{c}\mathrm{SO}_{4}{ }^{2-}, \\
\mathrm{mg} / 1\end{array}$ \\
\hline 0.8 & $2 \pm 2$ & 0 & 0 & 12.70 & 16.50 & $\mathrm{nd}$ & $\mathrm{nd}$ & $\mathrm{nd}$ & $\mathrm{nd}$ \\
1.1 & $15 \pm 6$ & 0 & 0 & 12.75 & 14.48 & $\mathrm{nd}$ & $\mathrm{nd}$ & $\mathrm{nd}$ & $\mathrm{nd}$ \\
1.5 & $38 \pm 5$ & 0 & 0 & 12.79 & 13.72 & $\mathrm{nd}$ & $\mathrm{nd}$ & $\mathrm{nd}$ & $\mathrm{nd}$ \\
1.8 & $41 \pm 5$ & $1.5 \pm 0.7$ & 2 & 12.91 & 12.86 & 2160 & 1824 & 69 & 97 \\
3.2 & $89 \pm 3$ & $4.8 \pm 1.1$ & 13 & 12.92 & 10.82 & 1360 & 1455 & 361 & 128 \\
4.6 & $100 \pm 7$ & $8.6 \pm 0.7$ & 27 & 12.91 & 9.32 & 940 & 1154 & 255 & 111 \\
7.5 & $95 \pm 4$ & $14.3 \pm 1.7$ & 42 & 12.84 & 8.99 & 615 & 1082 & 113 & 112 \\
14.5 & $98 \pm 6$ & $16.3 \pm 1.3$ & 50 & 12.89 & 8.31 & 330 & 1034 & 344 & 156 \\
\hline
\end{tabular}

nd - not determined, ${ }^{*}$ - data are the means of four replications \pm standard deviation

The after-germination of seeds in water showed that the water extracts with $\mathrm{L} / \mathrm{S}$ ratio of 1.1 and 1.5 inhibited germination reversibly, i.e. germination of the seeds exposed to the semi-coke water extract was later possible in water and the emerged seeds also showed radicles. The stronger water extract $(\mathrm{L} / \mathrm{S}=0.8)$ had toxic non-reversible effect on seeds, after-germination in water was not achieved. The latter was similar to the effect of fresh 
semi-coke, in which case it was not possible to germinate the seeds even afterwards.

\section{Influence of water extracts of semi-coke on seed germination}

It has been proposed $[2,25]$ that the negative influence of semi-coke on seeds can be caused by high $\mathrm{pH}$. The tests carried out in this study revealed that the is not the main reason for inhibition of seed germination. The various water extracts tested, although having similar $\mathrm{pH}$ values, showed totally different effects on seed germination and radicle growth (Table 5).

Semi-coke contains a considerable amount of soluble inorganic compounds (Tables 4 and 5). Concentration of calcium ions in water extracts was high, and the concentration of magnesium ions ca $3-5 \%$ of the calcium value. Also, the high concentration of sulphur-containing compounds is worth mentioning. This results in a high concentration of different ions and therefore in a high electrical conductivity of the water extracts prepared from it. The EC value in soil is an important parameter for evaluating the appropriateness of growth media to seed germination or plant growth. Salinity effects are considered mostly negligible in saturated extracts of soils [26], with EC of $2 \mathrm{mS} / \mathrm{cm}$ at $25^{\circ} \mathrm{C}$ or less [27, 28], but those effects become important with increasing EC values. EC values $>4 \mathrm{mS} / \mathrm{cm}$ in soil water can have a negative influence on full-grown plants [29]. If the EC of soil water increases, the water potential decreases, and therefore water absorption by seeds slows down [30]. This can slow germination, but it can also result in the dormancy of seeds, which stops after their placement into water [16].

By taking into account the data in Table 5, the above-mentioned increasing negative effect of water extracts can be explained by an increasing concentration of different ions in them (increasing values of EC). The results of the statistical analysis of the data presented in Table 5 show that germination index is significantly correlated with the $\mathrm{EC}$ and calcium content, indicating that these parameters could cause the inhibition of seed germination and radicle elongation (Table 6). The EC correlated well $(\mathrm{r}=0.99, \mathrm{p}<0.001)$ with the content of calcium ions in the studied extracts; the correlation of concentration of sulphur-compounds with EC was weak.

Table 6. The correlations between germination rate and radicle length, and chemical characteristics of water extracts

\begin{tabular}{|l|l|l|l|}
\hline & EC & Total hardness & Calcium ions \\
\hline Germination rate & $-0,89 * *$ & $-0,89 * *$ & $-0,93 * *$ \\
Radicle length & $-0,64$ & $-0,94 * * *$ & $-0,92^{*}$ \\
\hline
\end{tabular}

$* \mathrm{p}<0,05, * * \mathrm{p}<0,01, * * * \mathrm{p}<0,001$ 


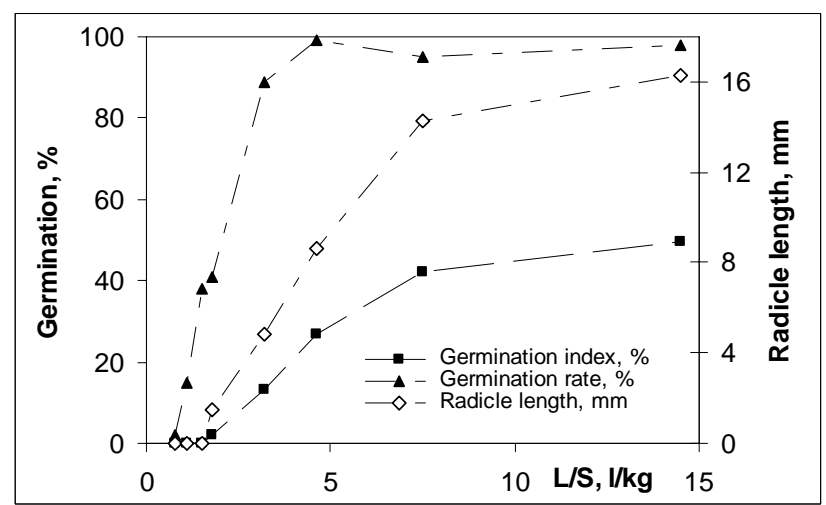

Fig. 1. Correlation between liquid/solid ratio used in preparation of water extracts and its effect on seed germination

Since the level of EC value having no negative effect on seeds was exceeded in all the water extracts studied, extracts of different electrical conductivities were prepared and investigated in an extra series of tests (Figures 2 and 3).

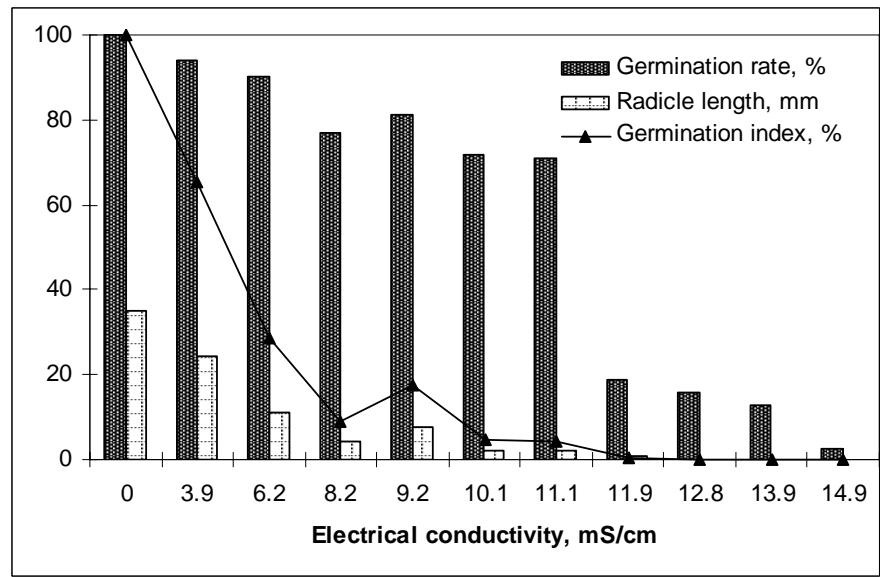

Fig. 2. Correlation between electrical conductivity of semi-coke water extracts and seed germination

Figure 2 shows that radicle length and germination index deduced from it decreased sharply with increasing electrical conductivity of semi-coke water extracts. Germination and radicle elongation in semi-coke water extracts differed from that in water already at electrical conductivity of $3.8 \mathrm{mS} / \mathrm{cm}$. A sharp decrease in germination was observed at the EC value around $11 \mathrm{mS} / \mathrm{cm}$; values $>15 \mathrm{mS} / \mathrm{cm}$ inhibited germination completely. The latter 


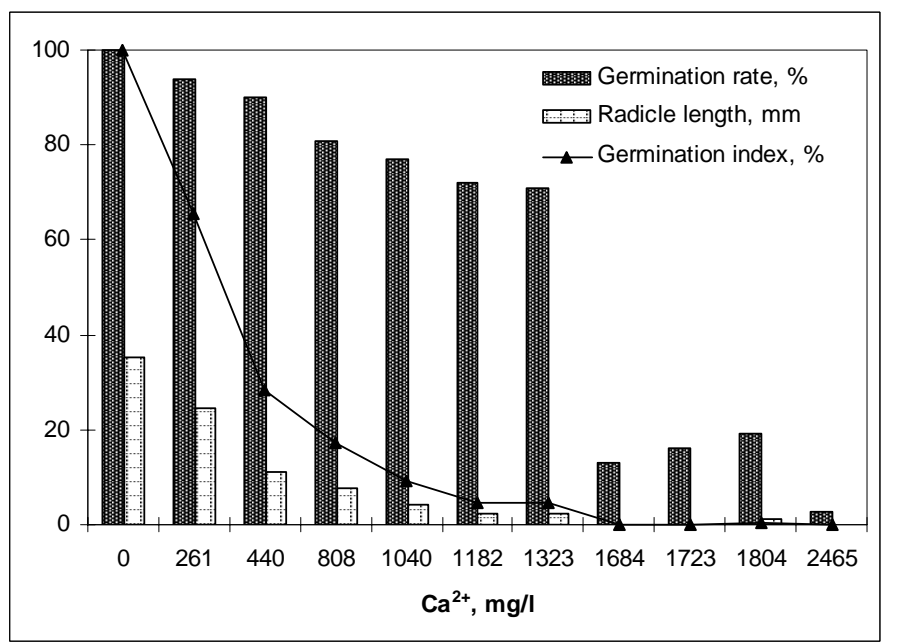

Fig. 3. Correlation between calcium ion content of the aqueous extracts of semi-coke and seed germination

value was also the limit at which seeds did not germinate even after replacing them into pure water. Radicle length, more than germination, was influenced by the increasing EC values. A $50-\%$ decrease in radicle length was seen at the EC value of $4.8 \mathrm{mS} / \mathrm{cm}$, and there was no radicle growth at $\mathrm{EC}$ values higher than $11 \mathrm{mS} / \mathrm{cm}$. The conditions for germination can be best characterized by germination index. A decrease in germination index of ca $50 \%$ was observed in the case of EC around $5 \mathrm{mS} / \mathrm{cm}$, and it fell to zero at an EC value around $12 \mathrm{mS} / \mathrm{cm}$. These values can be characterized by calcium ion concentrations of approximately 400 and $1800 \mathrm{mg} / \mathrm{l}$, respectively (Fig. 3).

Besides the good correlation between germination parameters and EC values of semi-coke water extracts, a good correlation with calcium content was also noted (Table 6, Fig. 3). It is well known that calcium is an essential plant nutrient but that, in excess, it can restrict plant communities on calcareous soils. When excessive calcium ions are present in the rhizosphere solution, plants may suffer calcium toxicity, which may prevent germination of seeds and reduce plant growth rates [31]. However, information on toxic effects of calcium ions is limited.

\section{Conclusions}

Fresh semi-coke completely blocked the germination of timothy seeds. The results of different tests showed that the inhibition of germination found at applying semi-coke samples from a correctly operated technological process is caused mainly by a high content of soluble salts. The investigation of 
semi-coke water extracts and their influence on seeds revealed that much of calcium and other ions causing high electrical conductivity of the solutions can be washed out from semi-coke. The results coincide with the results with washed semi-coke samples which inhibited seeds less than the fresh semicoke. We could also expect the negative effect of $\mathrm{pH}$, especially on the radicle growth, which turned out to be more sensitive than germination rate. Therefore, our study also confirmed that germination index is a better parameter for estimating inhibition than germination rate as it integrates the effects of any environmental stress on both germination and seedling growth stages.

We also conclude that experiments with water extracts of solid samples may not reflect the actual inhibiting effect of the growth media, especially if germination inhibition is a result of salinity. In this case, changes in germination index with dilution of the extract would be expected, and applying higher dilutions in preparing the extracts for the test, as has been done in several cases, might yield misleading results.

\section{Acknowledgements}

Support for this research by the Estonian Science Foundation (Grant No. 5811) is gratefully acknowledged.

\section{REFERENCES}

1. Truu, J., Talpsep, E., Velder, E., Heinaru, E., Heinaru, A. Enhanced biodegradation of oil shale chemical industry solid wastes by phytoremediation and bioaugmentation // Oil Shale. 2003. Vol. 20, No. 1. P. 421-428.

2. Raave, H., Kuldkepp, P., Leedu, E., Merivee, A. Recultivation substance and compost produced from semi-coke: The effect on soil characteristics, the yield of field crops and environment // Oil Shale. 2004. Vol. 21, No. 1. P. 59-73.

3. Raave $H$. Recultivation of oil shale semi-coke dumps with grasses and legumes: problems and potential // Integrating Efficient Grassland Farming and Biodiversity / Proceedings of the International Occasional Symposium of the EGF. Tartu. 2005. P. 153-157.

4. Blum, U., Rebbeck, J. Inhibition and recovery of cucumber roots given multiple treatments of ferulic acid in nutrient culture // Journal of Chemical Ecology. 1989. Vol. 15, No. 3. P. 917-928.

5. Kuiters, A. T. Effects of phenolic acids on germination and growth of herbaceous woodland plants // Journal of Chemical Ecology. 1989. Vol. 15, No. 2. P. 467-479.

6. Feng, L., Wang, L., Zhao, Y., Song, B. Effects of substituted anilines and phenols on root elongation of cabbage seed // Chemosphere. 1996. Vol. 32, No. 8. P. $1575-1583$. 
7. Henner, P., Schiavon, M., Druelle, V., Lichtfouse, L. Phytotoxicity of ancient gaswork soils. Effect of polycyclic aromatic hydrocarbons (PAHs) on plant germination. // Organic Geochemistry. 1999. Vol 30, No. 8. P. 936-969.

8. Wang, X., Yu, J., Wang, Y, Wang, L. Mechanism-based quantitative structureactivity relationships for inhibition of substituted phenols on germination rate of Cucumis sativus // Chemosphere. 2002. Vol. 46, No. 2. P. 241-250.

9. Carballeria, A. Phenolic inhibitors in Erica australis L. and in associated soil // Journal of Chemical Ecology.1980. Vol. 6, P. 593-596.

10. Chaves, N., Escudero, J. C. Allelopathic effect of Cistus ladanifer on seed germination // Functional Ecology. 1997. Vol. 11, No. 4. P. 432-440.

11. Póllumaa, L., Maloveryan, A., Trapido, M., Sillak, H., Kahru, A. Study of the Environmental Hazard Caused by the Oil-Shale Industry Solid Waste // ATLA. 2001. Vol. 29, No. 3. P. 259-267.

12. Orupõld, K., Tenno, T., Henrysson, T. Biological Treatment by Lagooning of Oil Shale Semicoke Ash Heaps Leachate Containing Phenolic Compounds // Water Research. 2000. Vol. 34, No. 18. P. 4389-4396.

13. Otsa, E., Tang, H. The determining of environmental hazard of semi-coke. The report of the Estonian Environmental Research Centre.-Tallinn, 2003 [in Estonian, summary in English].

14. Maves Ltd. Dry sedimentation of oil shale semi-coke and production of recultivation substance from it. Assessment of the effect on the environment. Aruande projekt Maves AS (Draft report of Maves Ltd). - Tallinn, 2001 [in Estonian].

15. Kahru, A., Kurvet, M., Kurvet, I. Study of the toxicological impact of different components of ash-heap water (sulphur rich phenolic leachate) using luminescent bacteria as test organisms // Oil Shale. 1997. Vol.14, No. 4 Special. P. 469-475.

16. Ungar, I . A. Effect of salinity on seed germination, growth and ion accumulation of Atriplex patula (Chenopodiaceae) // Am. J. Bot. 1996. Vol. 83, No. 5. P. 604-607.

17. Kahn, M. A., Ungar, I. A. The effect of salinity on the growth, water status and ion content of a leaf succulent perennial halophyte Sueda fruticosa (L.) Forssk. // Journal of Arid Environments. 2000. Vol. 45, No. 1. P. 73-84.

18. Prado, F. E., Boero, C., Gallardo, M., Gonzalez, J. A. Effect of $\mathrm{NaCl}$ on germination and soluble sugar content in Chenopodium quinoa Willd..seeds // Bot. Bull. Acad. Sin. 2000. Vol. 41, No. 1. P. 27-34.

19. Hayward, H. E., Bernstein, L. Plant growth relationship on salt -affected soils // Botanical Review. 1958. Vol. 24, P. 584-635.

20. Treshow, M. Mineral toxicity // Environment and plant response/ New York.: McGraw-Hill, 1970. P. 222-236.

21. Rabotnov, T. A. Grassland Ecology (Работнов, Т. А. Луговедение) - Moscow 1974 [in Russian].

22. International Rules for Seed Testing, Rules 1996 - International Seed Testing Association, Zurich, 1996.

23. American Public Health Association, Standard methods for the examination of water and wastewater, Washington D.C., 1986.

24. Orupõld, K., Raave, $H$. Phytotoxicity of oil shale semi-coke and its constituents // Life Sciences 2004. Book of abstracts $/ 9^{\text {th }}$ International conference on life sciences of Slovenia and $1^{\text {st }}$ international congress of toxicology in Slovenia. 2004. P. 236. 
25. Turbas, E. Chemical amelioration of soil - Taimede toitumise ja väetamise käsiraamat (Plant nutrition and fertilization handbook), Tallinn, 1996. P. 67101 [in Estonian].

26. U.S. Salinity Laboratory Staff. Saturated soil paste. Diagnosis and improvement of saline and alkaline soils // Agronomy Handbook 60, USDA, Washington, D.C. 1954

27. Patrick, Z. A., Toussoun, T. A., Snyder, W. C. Phytotoxic substances in arable soils associated with decomposition of plant residues // Phytopathology 1963. Vol. 53, P. 152-161.

28. Mengel, K., Kirkby, E. A. Principles of Plant Nutrition. - International Potash Institute, Bern, 1987.

29. Brady, N. C. The nature and properties of soils (10th Edition), Macmillan Publishing Company, UK, 1990.

30. Prado, F. E., Gonzales, J. A., Gallaro, M., Moris, M., Boero, C., Kortsarz, A. Changes in soluble carbohydrates and invertase activity in Chenopodium quinoa ("quinoa") developed for saline stress during germination // Cur. Top. Phytochem. 1995. Vol. 14, P. 1-5.

31. White, P. J., Broadley, M. R. Calcium in Plants // Annals of Botany. 2003. Vol. 92, No. 4. P. 487-511.

Presented by L. Reintam

Received April 21, 2006 